\title{
TEOLOGIA DAS RELIGIÕES: NOVO PARADIGMA DO PENSAR TEOLÓGICO
}

\author{
THEOLOGY OF RELIGIONS: NEW PARADIGM OF THEOLOGICAL THINKING
}

\author{
José Armando Vicente ${ }^{1}$
}

RESUMO: O tema da teologia das religiões vem ganhando a cada dia uma importância mais decisiva no cenário da reflexão teológica contemporânea. De fato, a teologia das religiões é um tema teológico recente. Podemos dizer que a ela teve seu nascimento na época do Concílio, ou seja, nos anos que lançaram suas premissas mais imediatas e nos que se seguiram. O tema é, portanto, extremamente complexo e sua abordagem exige um tratamento cuidadoso. A teologia das religiões estuda, à luz da fé cristã, a experiência comum a toda a humanidade como uma "espera anônima" do mistério de Cristo. A teologia das religiões é parte integrante do discurso teológico da Igreja. Queremos alertar, aqui, que a teologia cristã das religiões, embora sendo necessariamente "confessional”, não deve, porém, ser provinciana ou bairrista. Pelo contrário, ela deve adotar uma perspectiva global que abarque, na sua visão, a totalidade da experiência religiosa da humanidade. Do ponto de vista da fé cristã surgem as seguintes questões: De que maneira as realidades em que as pessoas vivem sua vida religiosa entram no projeto de Deus para a salvação da humanidade? Aos olhos de Deus que significado tem a realidade do pluralismo religioso no mundo?

Palavras-chave: Pluralismo religioso. Teologia. Valor salvífico. Cristologia.

ABSTRACT: The theme theology of religions is gaining more and more decisive importance in the scenario of contemporary theological reflection. In fact, the theology of religions is recent theological issue. You can say that it had to launch its immediate premises and those that followed. The theme is therefore extremely complex, and its approach requires a treatment of the Christian faith, the experience common to all humanity as an "anonymous wait" for the mystery of Christ. Theology of religions is an integral part of the church's theological discourse. We want to warn here that the Christian theology of religions, while necessarily being "confessional", should not adopt a global perspective that embraces, in its view, the totality of the religious experience of humanity. From the point of view of Christian faith the following questions arise: How do the realities in which people live their religious life come into God's plan for the salvation of humanity? In the reality of religious pluralism in the world mean?

Keywords: Religious pluralism. Theology. salvific value. Christology.

\footnotetext{
${ }^{\mathrm{I}}$ Doutor em Teologia Sistemática pela Faculdade Jesuíta de Filosofia e Teologia - Belo Horizonte - Brasil. Doutorando em Educação pela Universidade Internacional Iberoamericana - UNINI-MX. Linha de Pesquisa: Multiculturalidade, Interculturalidade em educação. Pós-graduando em Educação Bilíngui e Plurilíngui na PUC - MG (Pontifícia Universidade Católica de Minas Gerais.Graduado em Filosofia (1999), no Seminário Maior de Filosofia em Moçambique; graduado em Teologia (2005) no Instituto Santo Tomás de Aquino - Belo Horizonte - Brasil; - Pósgraduação Lato Sensu em Especialização para Formadores de Presbíteros (2010), no Instituto Santo Tomás de Aquino Belo Horizonte - Brasil; Pós-graduação Lato Senu em Especialização em Sociologia e Psicologia Social (2019), na Universidade Estácio de Sá; Mestre em Teologia Sistemática (2012) pela Faculdade Jesuíta de Filosofia e Teologia - Belo Horizonte - Brasil. Pesquisador nas seguintes áreas: Teologia das religiões; Pluralismo religioso. Diálogo Inter-religioso; Teologia Africana; as religiões; Educação: Multiculturalismo e Interculturalidade; Bilíngüismo e Plurilínguismo, Multilinguismo.E-mail: josarvicente@yahoo.com.br
} 


\section{INTRODUÇÃO}

O objetivo destas linhas é oferecer uma introdução à recente discussão teológica em torno da "teologia das religiões". A principal preocupação é de ordem informativa, isto é, deixar que falem os que escreveram sobre o assunto nestes últimos anos. Não se tem a pretensão de ser completo, pois existe uma vasta bibliografia publicada. Nem se pode oferecer uma conclusão clara sobre todos os pontos desta problemática.

Abordar-se-ão: a) a pluralidade das religiões; b) nomenclatura, conteúdo da teologia das religiões e fatores que influenciaram para o surgimento de tal teologia; b) método da teologia das religiões; c) história da teologia das religiões e as posições teológicas; e) a atual discussão cristológica; f) conclusão e/ou novos modelos teológicos

\section{PLURALISMO DE FATO OU A PLURALIDADE DAS RELIGIÕES}

A pluralidade das religiões, na verdade, não é fenômeno novo na história da humanidade. Ao longo dos últimos milênios, as religiões ditas primitivas foram florescendo e as grandes religiões se desenvolviam. Porém, a pluralidade das religiões tinha uma característica peculiar: antes de 1492, as religiões estavam ligadas às raças, à cultura, à geografia e, até, à decisão dos governantes. Basta lembrar que o Hinduísmo floresceu na Índia, o Budismo difundiu-se em todo o Extremo Oriente; o Islamismo desenvolveu-se no Oriente Próximo, no Oriente Médio e no norte da África; o Cristianismo, no Ocidente e no Oriente Médio; o Judaísmo no Oriente Médio; o Xintoísmo no Japão, o Confucionismo e o Taoísmo na China, as religiões naturais e as indígenas quase por toda a parte (BALASURIYA,2007, p. 20). Portanto, as religiões estavam, geralmente, confinadas no interior de áreas geográficas e culturais precisas e às suas pátrias de origem no continente. Após 1492, houve uma mudança bem significativa na distribuição mundial da população segundo as religiões.

Hoje, a pluralidade das religiões constitui um dado histórico; apresenta-se com uma nova aparência; ela é intracultural e se desenvolve no interior de um mesmo espaço geopolítico. Atualmente, a grande maioria (85\%) da população mundial tem religião. A terça parte da população é cristã, com um crescimento de 1,4\%. A quinta parte da população mundial é muçulmana, com uma taxa de crescimento maior de 2,1\%. 
O Islã é a religião que mais cresce no mundo, com mais de um bilhão de crentes e não cessa de conquistar novos territórios. Cresce principalmente no Ocidente. Em vários países da Europa, o Islamismo já é a segunda religião. Na Europa fala-se de um islãeuropeu que conta com mais de 15 milhões de membros, sem se falar do Budismo e do Hinduísmo. Na Alemanha encontram-se 3 milhões de muçulmanos e ıoo.ooo de judeus; na França os muçulmanos são 4 milhões, na Inglaterra 3 milhões (KUSCHEL, 2004, p. 78). Nos Estados Unidos da América, existem 8 milhões de seguidores; o Budismo é a religião emergente. Encontram-se templos em todas as grandes cidades do país.

O mundo religioso fragmenta-se, não somente por divisões internas, mas também pelo surgimento e proliferação surpreendente de novas religiões. Com isso, na atualidade, calcula-se que existem umas io.0oo religiões diferentes (KUSCHEL,2004, p. 47).

O Cristianismo, portanto, "se vê rodeado de concorrentes, numa incômoda situação já caracterizada como a de um mercado de bens religiosos” (MIRANDA, 1995, P. 324). Ele não é, portanto, a única maneira de olhar o mundo, não é a única religião que dita as normas, as práticas, os sistemas, as organizações.

O século XXI aparece não como o século que poderia trazer o fim da religião, mas como um século caracterizado por um vigoroso renascimento do interesse religioso. As religiões se registram no mesmo espaço público e aparecem em todos os lados. A questão da pluralidade das religiões é uma realidade do mundo de hoje que se encontra assaltado tanto das antigas e tradicionais, das grandes e pequenas religiões.

Como conceito, pode-se dizer que, hoje, em termos fenomenológicos, o termo "pluralidade das religiões" refere-se ao fato de que a história das religiões mostra uma pluralidade de orientações e variações dentro do mesmo espaço público. Significa uma situação na sociedade onde existe uma pluralidade de orientações religiosas, numa situação de coexistência ou de competição. "Designa simplesmente a situação em que uma variedade de perspectivas e de práticas religiosas coexistem na tolerância. É o elemento da tolerância que distingue o pluralismo da simples coexistência de diferentes crenças e práticas" (BERGERON, 2009, p. 96).

Do ponto de vista da fé cristã surgem as seguintes questões: a pluralidade das religiões é um fenômeno de fato ou de princípio? Ela constitui um mal a ser eliminado; é uma realidade negativa, pecaminosa, contrária a vontade de Deus? As religiões devem ser atribuídas ao poder do demônio, sendo feitas de politeísmo, de idolatria e de práticas imorais? De que maneira as realidades 
em que as pessoas vivem sua vida religiosa entram no projeto de Deus para a salvação da humanidade?

\section{NOMENCLATURA, FATORES E CONTEÚDO DA TEOLOGIA DAS RELIGIÕES}

A teologia das religiões não apresenta ainda um estatuto epistemológico bem definido. Pois se trata de um tema recente originado da influência de diversos fatores/causas. Entre esses fatores, elencamos:

a) uma proximidade inédita do cristianismo com outras religiões;

b) a enorme riqueza de conhecimentos sobre as mesmas hoje disponíveis;

c) o testemunho moral de muitos membros destas religiões;

d) o escasso fruto recolhido depois de anos de trabalho missionário em algumas nações;

e) a relativização das religiões devido a sua pluralidade, acentuada ainda pela compreensão das mesmas como sistemas simbólicos funcionais;

f) uma má consciência da parte de alguns teólogos cristãos com relação à atividade missionária do passado, unida à política colonial das grandes potências européias;

g) a atração exercida no ocidente pelas religiões orientais (MIRANDA, 1994, p. 09).

A teologia das regiões surge como parte integrante do discurso teológico da Igreja, ao qual pode ser aplicada a definição de Santo Anselmo: "fides quaerens intelecto" (fé que busca o intelecto).

Ao contrário das ciências da religião que procuram observar, avaliar e comparar os fenômenos religiosos exteriormente, a teologia das religiões principia, e continua em todas as fases, dentro de uma perspectiva de fé, com os pressupostos que esta implica (Dupuis, 1999, p. 17). Ela interpreta os dados na perspectiva de uma adesão pessoal a uma fé religiosa e reivindica o direito de expressar, dentro de tal perspectiva, juízos de valor.

A teologia das religiões estuda (conteúdo) as várias tradições religiosas, no contexto da história da salvação e na sua relação com o mistério de Jesus Cristo e com a Igreja. Diria Dupuis, citando Boublik, que a teologia das religiões estuda "a experiência religiosa vivida concretamente pelas pessoas no contexto das respectivas tradições religiosas, procurando interpretar esta experiência existencial dos 'outros' à luz da fé cristã e do mistério de Jesus Cristo" (Dupuis, 1999, p. 22). A teologia das religiões prioriza a realidade à abstração, a 
existência à essência. De fato, o que importa para ela é a experiência vivida das pessoas nas circunstâncias concretas em que Deus as colocou, e não nas definições.

A terminologia "teologia das religiões" vem sendo substituída gradualmente pela outra expressão "pluralismo religioso”. A mudança não indica simplesmente a mudança de terminologia, mas indica, sobretudo, uma alteração de perspectiva teológica.

Diz Dupuis:

A nova perspectiva não é mais limitada ao problema da 'salvação' dos membros das outras tradições religiosas, e nem mesmo à questão do papel de tais tradições na salvação dos seus seguidores. Ela busca, com mais profundidade, à luz da fé cristã, o significado, no projeto de Deus para a humanidade, da pluralidade das fés vias e das tradições religiosas que nos cercam (Dupuis, 1999, p. 25).

O exposto vem demonstrar que a atual teologia das religiões não considera a pluralidade das religiões simplesmente como uma evidência e como um fato da história (pluralismo de fato), mas como algo que tem uma específica razão de ser (pluralismo de iure ou de princípio).

Portanto, a questão não mais consiste, simplesmente, em perguntar-se que papel o cristianismo pode atribuir às outras tradições religiosas históricas, mas em procurar a raiz do próprio pluralismo, o seu significado no projeto de Deus para a humanidade, a possibilidade de uma convergência das várias tradições, com pleno respeito pelas suas diferenças, o seu mútuo enriquecimento e a sua recíproca fecundidade. Nesta ordem de pensamentos, podemos dizer que uma teologia das religiões se torna uma teologia "interreligiosa", com um imperativo universal.

Não custa lembrar que durante muitos anos as religiões foram abordadas e estudadas sob diferentes pontos de vista ou posições teológicas. Abordaremos com mais profundidade essas posições teológicas, nas páginas que se seguem. Por ora, afirmamos que:

- O primeiro quarto de século foi dominado por uma atitude apologética, em grande parte negativa. A questão que continua a reter a atenção dos teólogos era a possibilidade de salvação para os seguidores das outras religiões; a "salvação dos infiéis";

- Na metade do século, e nos anos que precederam e que imediatamente seguiram o concílio Vaticano II, houve uma mudança gradual de clima, graças a um poderoso impulso do Concílio. A abordagem das religiões deu-se de maneira menos defensiva e mais positiva. Diz Dupuis: 
$\mathrm{Na}$ onda do Concílio, a teologia passou a ser mais afirmativa e otimista em relação à salvação dos seguidores das outras religiões; as mesmas tradições foram gradualmente consideradas como portadoras de valores significativos, ou mesmo como detentoras de um papel positivo na salvação de seus seguidores. Com esta nova abordagem nasceu, como foi comentado, a teologia das religiões (Dupuis, 1999, p. 28).

- Terceiro período é aquele no qual entramos nos últimos anos: pode ser traçado a partir do início da década de 8o. Como afirmamos, a nova perspectiva procura penetrar mais profundamente no projeto de Deus para a humanidade. Ela pergunta-se sobre o significado que a pluralidade das religiões tem em tal projeto e, consequentemente, no desdobramento da história da relação de Deus com a humanidade, à qual damos o nome de história da salvação.

\section{MÉTODO DA TEOLOGIA DAS RELIGIÕES}

Faz-se necessário, antes de abordar o método da teologia das religiões, fazer um rápido exame dos métodos que se sucederam em um limitado espaço de tempo.

- método dogmático: este tomava como ponto de partida os enunciados dogmáticos da Igreja, cujo conteúdo tentava verificar em citações da Bíblia escolhidas de propósito para esse fim. Depois de escutar tal verificação, o método passava a uma ulterior pesquisa do significado dos dados dogmáticos, com a esperança de extrair dali conclusões teológicas cada vez mais precisas. Não é nossa intenção apresentar os limites e os riscos desse método. O que deve ficar claro, é que o método foi criticado pelo seu caráter abstrato. Por isso, o método dogmático foi substituído pelo outro.

- método genérico: este método parte dos dados revelados e depois expõe-se a compreensão e a interpretação que estes receberam ao longo da história, na tradição dos Padres e dos concílios, chegando até as escolas teológicas e autores recentes. Este método é recomendado pelo concílio Vaticano II. No decreto Optatam Totius se lê:

A teologia dogmática ordene-se de tal forma que os temas bíblicos se proponham em primeiro lugar. Exponham-se aos alunos o contributo dos Padres da Igreja do Oriente e Ocidental para a transmissão fiel e esclarecimento de cada uma das verdades da Revelação, e a história posterior do dogma, considerando a relação desta com a história geral da Igreja[...] (OT, n. i6).

Estes dois métodos (dogmático e genérico), embora apresentem diferentes pontos de partida (os enunciados dogmáticos - primeiro caso - e os dados bíblicos - no segundo), têm algo em comum: são métodos dedutivos; partem de afirmações de base para chegar a 
conclusões, do mais notório ao menos conhecido; partem de princípios gerais para chegar às suas aplicações concretas aos problemas atuais (DUPUIS, I999, p. 3I).

- método indutivo: este método não parte de princípios gerais para atingir as aplicações concretas, mas na direção oposta. Ele toma como ponto de partida a realidade experimentada atualmente, com todos os problemas que dela surgem, para procurar, à luz da mensagem revelada e mediante a reflexão teológica, uma solução cristã àqueles problemas. Este método é recomendado também pelo concílio Vaticano II, sobretudo na constituição dogmática Gaudium et spes. Esta inaugurou um novo método. A novidade consiste na passagem de um método dedutivo para um indutivo. Diz Dupuis: "a constituição dá ouvidos ao mundo de hoje e aos seus problemas, aprende a ler os 'sinais dos tempos' nas aspirações da humanidade hodierna, e depois procura esclarecer estes problemas e dar uma resposta a estas aspirações, à luz da mensagem do Evangelho" (DUPUIS, 1999, p. 31).

Adotar o método indutivo significa partir da realidade história, permitir que esta nos questione, e procurar lançar sobre ela a luz da palavra revelada; significa, sim, partir do contexto concreto, no qual a Igreja vive sua fé, e interpretar a realidade que nos rodeia com a ajuda da mensagem evangélica. Numa palavra, significa contextualização da teologia. Este modelo teológico dá origem:

- método hermenêutico: Claude Geffré definiu com propriedade a "teologia hermenêutica" como "um novo ato de interpretação do evento de Jesus Cristo, com base em uma correlação crítica entre a experiência cristã fundamental, testemunhada pela tradição, e a experiência humana contemporânea” (GEFFRÉ, op DUPUIS, 1999, p. 32). Esta nova interpretação da mensagem cristã nasce baseada em uma "circularidade entre a leitura de fé dos textos fundadores, por um lado, e a existência cristã atual, por outro lado.

A vida cristã é condicionada, em todos os lugares, pelo contexto histórico em que é vivenciada, com seus componentes culturais, econômicos, sociais, políticos e religiosos. Sendo assim, a teologia hermenêutica consistirá em um progresso e contínuo ir e vir entre a experiência contextual presente e o testemunho da experiência original, confiada à memória da tradição da Igreja - e vice-versa. Este contínuo ir e vir entre "contexto" e "texto", entre presente e passado, recebe o nome de "circulo hermenêutico".

$\mathrm{Na}$ verdade, não se trata de uma "circularidade" entre dois componentes, mas sim de uma "triangularidade" e de uma interação de três vértices: o "texto" ou o "dado" da fé, o 
"contexto" histórico e o "intérprete hodierno". Dessa maneira, a imagem do círculo pode ser substituída pela representação gráfica do triângulo. Mas cada um dos três pólos interativos - cada elemento do triângulo - deve ser visto em toda a sua complexa realidade. Quer dizer, por exemplo:

- o "texto" não significa apenas os dados revelados contidos na Bíblia, no caso, no Novo Testamento. O texto compreende, então, a Escritura, a Tradição e o Magistério da Igreja;

- o "contexto" são elementos constitutivos diferentes de lugar para lugar: aspectos sociopolíticos, econômicos e religiosos;

- o "intérprete". Não se trata simplesmente do teólogo individual, mas da comunidade eclesial à qual este pertence e a serviço da qual ele se encontra. Trata-se de uma igreja local, um povo que acredita e que vive sua experiência de fé em comunhão com toda a igreja - uma comunhão presidida na caridade pelo bispo de Roma.

Aplicando estes princípios à teologia das religiões, podemos fazer algumas considerações:

$I^{\underline{a}}$ : os teólogos ocidentais que se dedicaram à teologia das religiões adotam um método dedutivo: partem de certas afirmações do Novo Testamento que julgam ter um significado claro e indiscutível, e depois se perguntam que concessões a fé cristã pode fazer às outras tradições religiosas.

$2^{\underline{a}}$ : ao contrário, nas Igrejas em que a coexistência com outras tradições religiosas é parte integrante da vida de todos os dias, isto é, nas quais as grandes religiões do mundo se misturam cotidianamente, os teólogos puseram-se a defender um método rigorosamente indutivo. Começa-se com a práxis do diálogo inter-religioso entre as várias tradições e só depois, como "segundo ato", acontece a reflexão teológica sobre a relação entre tais tradições.

\section{- método teológico global:}

Dessas considerações, percebe-se, então, um problema hermenêutico, um dilema metodológico para a teologia das religiões. Nessa situação, a metodologia preferível para a teologia das religiões parece ser uma combinação do método dedutivo com o indutivo. Knitter chama essa abordagem de "método teológico global" e a descreve, aplicada ao nosso tema: teologia das religiões.

Diz Knitter: 
Todo método teológico praticável deverá servir-se de duas fontes - a tradição cristã (a Escritura e sua interpretação viva ao longo da história) e a experiência humana (incluindo tanto o pensamento como a práxis). Ambas as fontes devem ser ouvidas abertamente e com honestidade, ambas devem ser postas em uma correlação, reciprocamente esclarecedora e crítica.

Aplicando a abordagem das duas fontes a um método para uma teologia das religiões, devemos reconhecer que uma compreensão e uma abordagem cristã para as outras religiões não podem tomar forma apenas a partir da trama das crenças religiosas. Partiremos, certamente, daquilo que a Bíblia e as declarações oficiais dos concílios têm a dizer das outras religiões. E o que aí encontrarmos será considerado seriamente. Mas não será possível chegar a conclusões definitivas, a propósito do valor da verdade das outras tradições, enquanto os nossos "dados" não forem confrontados com o conhecimento (teoria) e a experiência (prática) concretos das outras religiões (KNITTER, op, DUPUIS, 1999,

Do exposto, percebemos que o método da teologia das religiões deve procurar manter um encontro entre o dado cristão e a práxis do diálogo. No entanto, se levarmos em consideração à sua freqüente omissão no passado, devemos insistir aqui o papel do diálogo, como fundamento necessário de uma teologia das religiões. Sendo assim, podemos afirmar que mais do que um novo tema para a reflexão teológica, a teologia das religiões deve ser vista como um novo modo para se fazer teologia em contexto inter-religioso: um novo método para se fazer teologia em situação de pluralismo religioso (D'COSTA, op, DUPUIS, 1999, p. 36).

Portanto, em contexto inter-religioso, a teologia das religiões tem seu ponto de partida na práxis do diálogo inter-religioso e, com base nesta prática, ela saí em busca de uma interpretação cristã da realidade religiosa pluriforme que a circunda.

\section{HISTÓRIA DA TEOLOGIA DAS RELIGIÕES E AS POSIÇÕES TEOLÓGICAS}

Como foi dito, a teologia das religiões é um tema recente. Ela teve seu nascimento no período pré-conciliar e, sobretudo, na época do concílio Vaticano II, na década de 6o. Basta lembrar os trabalhos de U. Von Balthasar, H. de Lubach, E, Cornelis, H. Fries, H Maurier, H. Nys, K. Rahner, H. R. Schlette, G. Thils e R. C. Zaehner. Costuma-se considerar que a primeira obra de teologia das religiões foi a de Heinz Schlette com o título As religiões como tema da teologia e publicada em 1963. Esse contexto, portanto, corresponde ao primeiro período da teologia das religiões.

Ao se tratar da salvação dos que ignoravam o cristianismo, várias e diferentes posições teológicas influíram. Em outras palavras, diferentes posicionamentos teológicos acarretaram classificações múltiplas: 
"Exclusivismo": (corresponde no âmbito cristão ao eclesiocentrismo): é a posição teológica segundo a qual há uma única verdadeira religião, a que foi revelada por Deus, e que possui a verdade em exclusividade, enquanto as outras religiões são falsas ou simplesmente humanas, naturais, incapazes de salvar (VIGIL, 2006, p. 63).

"Inclusivismo": (corresponde no âmbito cristão ao cristocentrismo): é a posição teológica segundo a qual, ainda que a verdade e a salvação estejam plenamente presentes numa determinada religião, também se fazem presentes nas outras religiões, mas como participação na verdade e na salvação presentes na única religião verdadeira. Esta posição divide-se em duas partes (VIGIL, 1999, p. 63):

- o inclusivismo da linha de J. Daniélou, H. de Lubac, Hans Urs Von Balthasar ou teoria do cumprimento ou acabamento: esta posição reconhece os valores positivos das outras religiões não-cristãs, mas encontram seu acabamento ou cumprimento no cristianismo. Segundo Teieira, "as diversas religiões não-cristãs representam a aspiração inata no homem à união com o Divino, porém essa aspiração encontra sua resposta em Jesus" (TEIXEIRA, 1995, p. 132). As religiões não cristãs são “religiões naturais” e o cristianismo é a religião sobrenatural. Elas são como degraus para o cristianismo, no qual encontram seu cumprimento (DUPUIS, 1999, p. 188).

- inclusivismo da linha de K. Rahner, Raimundo Panikkar, Hans Hüng, Gustave Thlis ou teoria da presença do mistério de Cristo nas religiões. Segundo esta teoria, as diversas tradições religiosas da humanidade contêm valores soteriológicos positivos para seus membros, pois nelas, e através delas, manifesta-se a presença operativa, oculta de Jesus Cristo e de seu mistério salvífico. Essa presença de Cristo nas outras religiões, acontece de maneira oculta e desconhecida aos seus membros.

Paul Knitter propôs mais três esquemas de classificação: I) - Modelo evangélico conservador (exclusivismo radical); - modelo protestante geral (inclusivismo); - modelo católico (inclusivismo); - modelo teocêntrico (pluralismo). 2) - Cristo contra as religiões (exclusivismo); - Cristo dentro das religiões (inclusivismo); - Cristo normativamente por cima das religiões (pluralismo normativo); - Cristo com as religiões (pluralismo). 3) modelo de substituição, total ou parcial (exclusivismo); - modelo de plenificação (inclusivismo absolutista); - modelo de cooperação (pluralismo); - modelo conformidade (pluralismo pós-moderno). 
Raimund Panikkar apresenta duas classificações: I) - exclusivismo; - inclusivismo; - paralelismo; - interpenetração. 2) - modelo geográfico: caminhos que conduzem ao cimo da montanha; - modelo físico: o arco-íris; - modelo geométrico: a variante topológica; modelo antropológico: a linguagem.

Juan José Tamayo propõe uma tipologia: I) - Cristo contra as religiões e a cultura: cristologia e eclesiologia anônimos; - Cristo por cima das culturas e dos cristãos anônimos; - harmonia entre Cristo e a cultura; - normatividade de Cristo para a salvação; - plurais manifestações de Deus e plurais mediadores; - salvação através da práxis histórica de libertação.

Otimismo do Concílio Vaticano II. A teologia do Concílio Vaticano II passou a ser afirmativa e otimista em relação à salvação dos seguidores de outras religiões; estas foram consideradas como portadoras de valores positivos. Os membros das outras tradições religiosas, segundo os textos conciliares, podem ser associados ao Mistério Pascal de um modo desconhecido por Deus. O Concílio Vaticano II vê nas outras tradições religiosas um "raio desta Verdade, que ilumina todos os homens" (NA 2); nelas há a presença de "sementes do Verbo" e "riquezas" (NA II). Reconhece positivamente que elas procuram encontrar respostas "aos enigmas escondidos da condição humana" (NA I) e alude ao bem semeado não só no "espírito e no coração dos homens", mas também "nos ritos e nos costumes dos povos" (LG ${ }_{17}$ ).

Em resumo, o Vaticano II satisfaz a primeira tarefa ao reafirmar a salvação de toda a humanidade em Jesus Cristo, mas não tratou explicitamente da outra, de tal modo que o sentido salvífico das religiões permaneceu confuso (MIRANDA, 1994, p. Io). Para Dupuis, o Concílio Vaticano oferece uma base que aponta para a afirmação de que as religiões são caminhos salvíficos para seus membros.

O Papa João Paulo II reconhece a ação do "Espírito de verdade operado fora dos limites visíveis do Corpo Místico" ( $\mathrm{RH}$ 6; RM 28; cf. DV 53). Ainda: "todos os homens e mulheres, são criados por Deus à sua imagem, dotados de um destino comum, dentro de um único plano salvífico em Jesus Cristo, com a presença ativa universal do Espírito Santo" (DA, 27-28). O documento "Diálogo e Anúncio" reconhece que as pessoas sinceras, inspiradas pelo Espírito de Deus, marcaram a elaboração e o desenvolvimento de suas tradições religiosas, embora nem tudo o que nelas se encontra seja "fruto da graça" (DA n. 30). 
Pluralismo: o termo "pluralismo" religioso refere-se à substituição da única mediação universal e constitutiva de Jesus Cristo pelas muitas "vias" ou figuras salvíficas que conduzem a Deus-Centro. As diferentes religiões - incluindo o cristianismo representam outras tantas vias que conduzem a Deus e cada uma delas possui, apesar das diferenças, a mesma validade e valor (DUPUIS, 1999, p. 260). O pluralismo é a posição teológica segundo a qual todas as religiões participam da salvação de Deus, cada uma por si mesma e a seu modo (VIGIL, 2006, p. 63). Nesta posição, o cristianismo deixa de ser o "único e exclusivo meio de salvação" e as outras religiões não-cristãs aparecem como realidades legítimas e autônomas de salvação, como religiões verdadeiras, e não como um cristianismo diminuído. No centro desta posição está Deus, e não Jesus Cristo. Deus torna-se o centro do desígnio salvífico da humanidade.

A posição pluralista teocêntrica divide-se em duas correntes, que analisaremos adiante, no item "Discussão Cristológica":

- o pluralismo teocêntrico com a cristologia não constitutiva, nem normativa e;

o pluralismo teocêntrico com a cristologia normativa e não constitutiva.

Portanto, os teólogos que defendem um pluralismo teocêntrico diferem sob vários aspectos, não sendo aqui necessário entrar em detalhes a esse respeito. A posição de Jhon Hick é de tal modo representativa da interpretação radical do pluralismo teológico que vale a pena dos determos.

John Harwood Hich nasceu em Scarborouhg, Yorkshire, na Inglaterra, em 1922 e faleceu em fevereiro de 2012. Filósofo e teólogo britânico, é o pioneiro da "teologia pluralista”; pertenceu à Igreja presbiteriana de Inglaterra desde 1940.

$\mathrm{Na}$ opinião de Christopher Partridge, John Hich não é só um dos pensadores religiosos radicais britânicos mais importantes, senão que não se pode desestimar o significado do seu pensamento nas questões que são colocadas pela pluralidade religiosa (PARTRIDGE, op, HURTADO, 2012, p. 12).

Por muitos anos, ele lecionou em diversas universidades: Cornell, Princeton e Claremont (EUA); Cambridge e Birmingham (Grã-Bretanha). Escreveu várias obras: God and the Universe of Faiths (1973); Christianity and Other Religions (1980); God Has Many Names (1982); An Interpretation of Religion (1989); The Metaphor of God Incarnete (1983). Dialogues in the Philosoph of Religion (20or); The Fifth Dimension.

Hick defende uma "revolução copernicana" da cristologia, uma revolução que deve consistir, especificamente, numa mudança de paradigma. 
Diz Dupuis:

\begin{abstract}
A expressão revolução copernicana, que hoje pode ser encontrada com freqüência também em outras áreas do debate cristológico, é especialmente adequada para aquilo que acontece em nosso caso. Originalmente, ela indicava a passagem de um sistema de explicação do cosmo, já ultrapassado e antiquado, para o outro sistema que efetivamente corresponde à realidade. Essa passagem aconteceu quando o sistema ptolomaico foi substituído pelo copernicano. Depois de termos crido durante séculos que o Sol girava em torno da terra, descobrimos finalmente, com Galileu e Copérnico, que na realidade era a terra que girava em torno do Sol. Do mesmo modo, depois de termos acreditado por séculos que as outras tradições religiosas giravam em torno do cristianismo, devemos agora reconhecer que, na realidade, o centro em torno do qual giram todas as religióes (o cristianismo incluído) é Deus. Tal mudança de paradigma implica necessariamente o abandono de qualquer reivindicação de um significado único não só para o cristianismo, mas também para o próprio Jesus Cristo (DUPUIS, 1999, p. 262).
\end{abstract}

Além da expressão "revolução copernicana", ouvimos também falar de "atravessar o Rubicão”. Em 49 a.C, César, sem autorização do Senado, ultrapassou o Rio Rubicão que separava a Itália de Gália Cisalpina. Portanto, as expressão “revolução copernicana” e “atravessar o Rubicão” significam tomar uma decisão audaciosa e irrevogável.

Teologicamente, são símbolos da renúncia a certas opções teológicas para se abrir a novas perspectivas. Diz Hurtado:

quer dizer renunciar ao monopólio cristão da verdade salvadora e da vida, expressa na doutrina extra ecclesia nulla salus, característica da posição cristã exclusivista com respeito à salvação. Mas também ela quer significar a necessidade de passagem da posição inclusivista à posição pluralista (HURTADO, 2012, p. 12).

Por sua vez, Dupuis afirma: "significa reconhecer de maneira irrevogável o igual significado e valor das diferentes religiões e renunciar a qualquer pretensão não só de exclusividade, mas também de normatividade, para o cristianismo ou para Jesus Cristo" (DUPUIS,1999, p. 263).

De forma geral, os teólogos pluralistas (do lado católico: H. Küng, Jacques Dupuis, Paul Knitter, Raimund Pannikar, Edward Schillebeeckx, Faustino Teixeira, M. Amalladoss...; do lado protestante: E. Troeltsch, John Hich, W. C. Smith, P. Tillich..), admitem o pluralismo de direito, um dado de princípio. De acordo com esses autores, o pluralismo religioso deve ser acolhido como um fator positivo que atesta a generosidade superabundante com que Deus se manifestou à humanidade e, ao mesmo tempo, a resposta multiforme que as pessoas deram à auto-revelação divina nas várias religiões.

O pluralismo religioso, portanto, tem um papel e um valor positivo aos olhos de Deus. Trata-se de um fenômeno rico e fecundo que tem sua razão de ser no próprio 
desígnio de Deus. A comunicação de Deus é diversificada. As diferentes religiões expressam os "diversos modos" com que Deus falou aos seres humanos. A pluralidade das religiões não constitui um mal a ser eliminado ou manifestação da pecaminosidade humana, e sim uma expressão da riqueza e diversidade de auto-comunicação de Deus ao gênero humano e a toda a criação.

Ela, em primeiro lugar, é um modo de ser do cosmos e da humanidade; em segundo lugar, é desejado por Deus e procede de seu misterioso desígnio. Assim, firma-se no âmbito da teologia uma posição que mantém a defesa do pluralismo religioso de princípio, isto é, de um pluralismo que não está ligado a uma situação histórica contingente, mas que se insere no desígnio misterioso de Deus.

Portanto, o pluralismo religioso tem seu fundamento principal na superabundância riqueza e variedade das automanifestações de Deus à humanidade. Como afirma a carta aos Hebreus, Deus "falou muitas vezes e de muitos modos" ( $\left.\mathrm{Hb}_{\mathrm{I}}, 2\right)$. O pluralismo religioso de princípio se fundamenta na imensidão de um Deus que é amor.

O pluralismo religioso, como tema teológico novo, é o "sinal dos tempos", fenômeno que caracteriza a nossa época, um kairós, isto é, um momento histórico que abre novos horizontes à teologia, que oferece novas chances para fazer teologia e uma possibilidade para uma compreensão do cristianismo. $O$ pluralismo religioso apela para uma nova maneira de fazer e pensar teologia. Apresenta-se como novo paradigma de fazer teologia.

\section{A DISCUSSÃO CRISTOLÓGICA}

A grande problemática do cristianismo se centralizou na "encarnação de Deus", que confere à pessoa de Jesus Cristo as características de "unicidade" e de "universalidade" em ordem da salvação da humanidade. Como pode um evento particular e histórico ter uma pretensão universal?

Esta preocupação deu lugar ao teocentrismo salvífico, que possibilita um pluralismo de mediações salvíficas e verdadeiras.

O pluralismo pretende ser uma superação do eclesiocentrismo e do cristocentrismo, uma mudança de paradigma, uma revolução copernicana (J. Hich).

Schineller e Dupuis distinguem dois tipos de pluralismo: 
- um pluralismo teocêntrico no qual Jesus Cristo não é constitutivo, mas é normativo da salvação. Os defensores desta posição são: E. Troeltsch, P. Tillich, P. Knitter, R. Panikkar. Nesta posição, sem negar que os outros possam também mediatizar a salvação, reconhece-se em Jesus Cristo o mediador que melhor a expressa. O amor de Deus se revela mais claramente em sua pessoa e obra. Cristo é assim o paradigma para os outros mediadores. Mas sem ele não ficaríamos sem salvação, e sim sem sua manifestação mais perfeita. Sem Jesus Cristo não faltaria a graça de Deus e sim a manifestação decisiva da mesma (Schineller).

- um pluralismo teocêntrico no qual Jesus Cristo não é constitutivo, nem normativo da salvação. Posição defendida por John Hich. Nessa posição, Jesus Cristo não é nem constitutivo, nem normativo para a salvação do homem. Deus é de tal modo transcendente e incompreensível que não podemos julgar seus desígnios por nossos padrões humanos. Para Hick, a encarnação é apenas uma expressão não objetiva, mas metafórica, poética e mitológica. Pretende apenas significar o amor de Deus encarnando-se em homens e mulheres, cujas vidas refletem a ação salvífica de Deus. Pode mesmo ocorrer, de diferentes formas e graus, e em muitas pessoas. Portanto, a conseqüência mais importante desta concepção é que Jesus Cristo não mais pode ser considerado o único e exclusivo mediador de Deus.

Deve ficar bem claro que os pluralistas teocêntricos não pretendem minar nem a adesão de fé dos cristãos, nem a totalidade das exigências que essa adesão dirige a pessoa. O que está em questão é o significado universal e a função constitutiva atribuídas pelo cristianismo a tal adesão.

A tese dos teólogos pluralistas é que crer em Jesus é crer que eu sou salvo por meio dele, não que ele é o salvador do mundo, isto é, a pessoa histórica de Jesus de Nazaré não é o caminho obrigatório para todos os seres humanos. Jesus é o caminho para os cristãos, mas a existência de outros caminhos faz com que ele não seja necessário também para os outros.

Portanto, a mudança do paradigma do teocentrismo gira inteiramente em torno do problema cristológico, isto é, gira em torno de uma cristologia revisionista que se afasta substancialmente da cristologia do cristianismo tradicional. Por isso, os teólogos ou defensores da perspectiva teocêntrica defendem a mudança de paradigma sobre uma cristologia revista, interpretada no contexto do pluralismo religioso. 
Fundamentalmente, as perguntas que se levantam dizem respeito, no contexto do diálogo, à necessidade de reexaminar e interpretar o testemunho inequívoco dado pelo Novo Testamento - que por si não é negado - ao significado universal de Jesus Cristo:

I) Esse testemunho pertence à substância da mensagem revelada ou é, pelo contrário, devido ao idioma cultural em que a experiência dos primeiros cristãos encontrou sua expressão e às circunstâncias em que tal experiência se deu?

2) À luz do que hoje sabemos a respeito das outras tradições e de seus seguidores, é ainda possível fazer com que a salvação de todos os seres humanos depende do indivíduo histórico Jesus de Nazaré, de quem eles jamais ouviram falar ou não foram capazes de reconhecer?

3) Mais radicalmente, que autoridade de "norma de fé" ainda conserva o testemunho neotestamentário se colocado diante da nossa atual experiência de diálogo?

Essas perguntas detêm a atenção da atual discussão cristológica.

\section{CONSIDERAÇÕES FINAIS: RUMO A NOVOS MODELOS TEOLÓGICOS?}

Uma das principais objeções feitas ao paradigma teocêntrico é o fato de ele assumir acriticamente um conceito da Realidade Absoluta afim com as religiões monoteístas e proféticas do hemisfério ocidental, mas completamente alheios às tradições místicas do oriente, da África, da América Latina. Pergunta-se: como é possível impor a todas as religiões uma ideia preconcebida de Deus, uma tentativa de mostrar que elas convergem, apesar de suas diferenças, num único Centro Divino?

Essa situação obrigou os defensores do pluralismo teocêntrico a propor outros modelos.

\section{reinocentrismo e soteriocentrismo:}

Hick propõe o modelo do "centramento sobre a Realidade". Quer dizer, todas as religiões são orientadas, de modos diferentes, para aquilo que consideram como a Realidade Central. Todas as religiões são voltadas para o que constitui a "Preocupação última" da humanidade. Em chave soteriológica, todas as religiões têm o poder de transformar as pessoas, conduzindo-as do "autocentramento" ao "centramento sobre a Realidade". 
Por sua vez, Knitter propõe substituir o modelo teocêntrico pelo que ele chama de "reinocentrismo" ou "soteriocentrismo". Para ele, todas as religiões propõem uma mensagem de salvação ou de libertação humana. Todas elas partilham a mesma potencialidade de se tornarem vias de salvação para seus seguidores. Numa linguagem cristã, isso significa que todas as religiões estão destinadas a serem sinais sensíveis da presença do Reino de Deus no mundo; todas podem e devem contribuir, sob aspectos diferentes, para o crescimento do Reino de Deus entre as pessoas e os povos. Seguidores das outras religiões são membros do Reino de Deus na história.

Portanto, com o modelo reinocêntrico, a teologia das religiões não se centra mais no evento-Cisto, e sim no Reino de Deus que se constrói ao longo da história e que está destinado a atingir sua realização no tempo escatológico.

O outro modelo proposto hoje como possível substituto do teocentrismo é o logocentrismo e pneumatocentrismo, isto é, a presença universal ativa no mundo e na história do Verbo de Deus (Lógos) e do Espírito de Deus (Pnêuma).

Segundo o modelo do logocentrismo, o acontecimento ou o evento-Cristo não esgota o poder ou a força do Logos, do Verbo de Deus, como tal. O Evangelho de são João atesta a ação iluminadora do Logos ao longo da história: "a luz verdadeira, aquela que ilumina todo homem, estava chegando ao mundo" (Jo I,9). O Verbo de Deus (cf. Sabedoria de Ecl 24) é fonte da luz para a humanidade, antes e depois da encarnação - sua iluminação e seu poder salvífico são universais (DUPUIS, 1999, p. 440).

Dupuis afirma, citando R. Schnackenburg no seu comentário a João I,9, que:

A capacidade do Logos de dar a vida e a luz é universal e necessária para todo homem. Nele, e apenas nele, existia o poder divino vital para o verdadeiro, espiritual ser dos homens, e nele, apenas nele, existia [...] a verdadeira luz divina para todo homem. No hino original desta afirmação [...] certamente ainda se referia à ordem da criação, isto é, ao Logos antes da sua encarnação. Desde modo lhe é atribuída a função que a literatura judaica atribuía à Sabedoria, e portanto, à Torá; de fato, no pensamento judaico a Torá assumiu a tarefa que era própria da Sabedoria [...]. Contudo, o hino cristão insiste em afirmar que o Logos, isto é, Cristo em sua existência pré-terrena, possuía essa capacidade e essa força, e em sua missão salvífica não faz outra coisa senão colocá-las em ação; e por isso porque elas lhe pertencem essencialmente e porque ele é a "verdadeira" luz [...]. Assim, o Logos possui uma incomparável força iluminadora, que deriva da sua divindade [...], que pode e deve se mostrar em todo homem que queira descobrir a sua mente (R. Schnackenburg, op, DUPUIS, 1999, p. 440). 
Da citação, percebe-se que o Logos é a força iluminadora dos seres humanos; ele é a única fonte de luz divina. As pessoas e empreendimentos humanos são iluminados pelo Verbo de Deus. Diz Dupuis:

Todavia, aqui também é preciso ter presente o caráter mundano e social do ser humano. Não era apenas cada uma das pessoas - Sócrates, Buda, (Cristos Negros...) - que podia receber a verdadeira luz do Logos; os empreendimentos humanos - a filosofia e sabedoria gregas, a sabedoria asiática ( a sabedoria e religião africanas) - também eram canais através dos quais a luz divina chegava até as pessoas. Isso significa que as tradições religiosas (a RTA) contêm elementos de "verdade e graça" ( $A G, 9)$, semeados nelas pelo Logos, através dos quais sua força e iluminação salvífica atuam. O Logos divino continua ainda hoje espalhando suas sementes em meio aos povos e nas suas tradições: a verdade revelada e a graça salvífica estão presentes neles mediante a sua atividade (DUPUIS, I999, p. 44I).

A iluminação e o poder salvífico do Logos não estão confinados pela particularidade do evento histórico. Rompem (transcendem) com qualquer barreira do espaço e do tempo. O poder iluminador e transcendente do Logos explica a função exercida pelas tradições religiosas na economia salvífica.

Observações parecidas podem ser feitas quando a economia universal, salvadora e vivificante do Espírito, do Pnêuma de Deus. A “a comunicação do Espírito por Cristo ressuscitado não esgota necessariamente a atividade do Espírito depois do acontecimento Cristo". Se é certo que não se pode construir uma economia "autônoma” do Espírito, desligada da economia da Palavra, também é certo que o Espírito não pode ser reduzido a uma "função" de Cristo ressuscitado, sendo assim seu "vicário" (DUPUIS, 1999, p. 25I). Entre o Filho e o Espírito há uma reciprocidade e o serviço mútuo, mas Pentecostes não é a continuação da encarnação.

Não há subordinação do Espírito em relação ao Filho: O Espírito "sopra onde quer" (Jo 3,8). A economia do Espírito não conhece limites de espaço e tempo.

O Espírito de Deus sempre esteve universalmente presente na história humana, e ainda hoje continua agindo fora dos limites do rebanho cristão. É ele quem inspira, nas pessoas que pertencem às outras religiosas, a obediência da fé salvífica, e nas mesmas tradições uma palavra dirigida por Deus aos seus seguidores. De fato, não se poderia pensar que, enquanto os cristãos obtêm a salvação mediante a economia do Filho de Deus encarnado em Jesus Cristo, os outros a recebam pela ação autônoma imediata do Espírito de Deus? A "independência hipostática" ou a distinção pessoal das duas "mãos" de Deus garante os dois canais distintos através dos quais a presença salvífica de Deus chaga às pessoas em duas diferentes economias de salvação (DUPUIS, 199, p. 275). 
A função salvífica do Espírito consiste em "centrar" as pessoas, mediante sua presença imanente, naquele Cristo que Deus estabeleceu como mediador e caminho que conduz até eles. A função específica do Espírito consiste em permitir às pessoas que se tornem participantes, antes ou depois do evento, do mistério da morte e ressurreição de Jesus Cristo (GS, n, 22). Assim, por meio do poder do Espírito, o evento Jesus Cristo age em todos os tempos; está presente e ativo em todas as gerações. Sempre e de qualquer modo, a influência imediata do Espírito dá expressão à presença operante da ação salvífica de Deus, que atingiu o seu ápice em Jesus Cristo.

Numa palavra, as duas "mãos" do Pai (Irineu), Palavra e Espírito, convergem na realização de uma só economia salvífica; a "iluminação" universal do Logos e a vivificação do Pnêuma possibilitam descobrir em outras figuras e tradições salvíficas verdade e graça.

\section{REFERÊNCIAS BIBLIOGRAFIAS}

BALASURIYA, Tissa. As religiões, especialmente o cristianismo, diante do futuro. Concilium. Petrópolis: Vozes, n. 319, 2007.

BERGERON, Richard. Fora da Igreja também há salvação. São Paulo: Loyola, 2009.

CONCÍLIO. Documentos do Concílio Vaticano II. São Paulo: Paulus: 200 .

DUPUIS, Jacques. Rumo a uma teologia cristã do pluralismo religioso. São Paulo: Paulinas, 1999.

KUSCHEL, Karl-Josef. Euro-Islão: desafio ou chance? Concilium. Petrópolis: Vozes, n.305, 2004 .

MIRANDA, Mario de França. O Encontro das religióes. Perspectiva teológica, n. 68, jan./abr. 1994 .

O Pluralismo Religioso como Desafio e Chance, Revista Eclesiástica Brasileira, Petrópolis: Vozes, v. 58, n. 218, jun. 1995.

TEIXEIRA, Faustino. Teologia das religiões: uma visão panorâmica. São Paulo: Paulinas, 1995.

VIGIL, José Maria. Teologia do pluralismo religioso. São Paulo: Paulus, 2006. 